Jusmal llmial

PEUR AA DE

Vol. 5, No. 2, May 2017

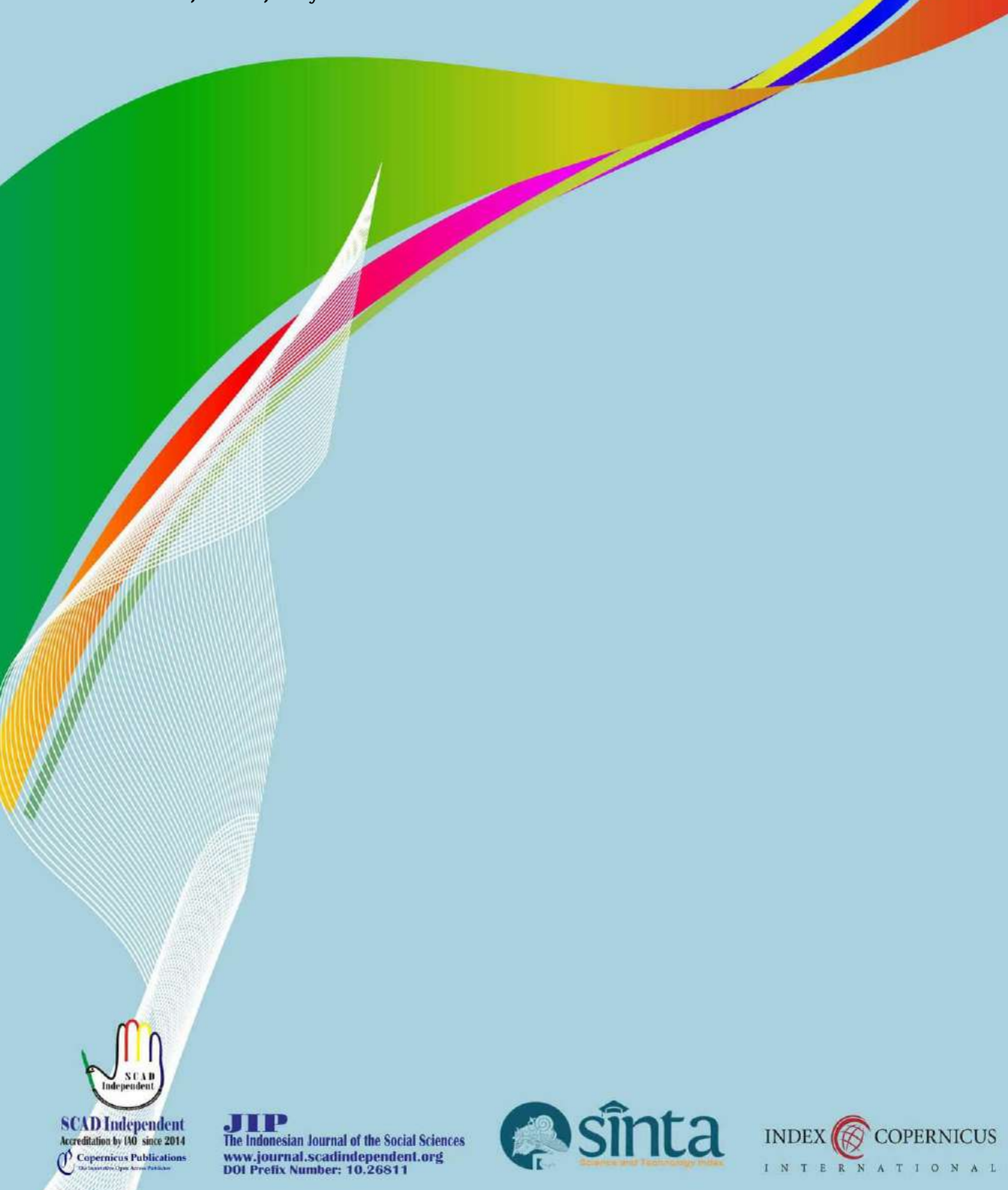




\title{
THE EFFECTIVENES OF MANAGERIAL SKILLS OF STATE ELEMENTARY SCHOOL PRINCIPALS IN EAST JAKARTA
}

\author{
Isthifa Kemal1 \& Eddy Setyanto ${ }^{2}$ \\ ${ }^{1}$ STKIP Bina Bangsa Getsempena, Banda Aceh, S3 Student Education Management, \\ State University of Jakarta, Indonesia \\ 2Indraprasta PGRI University, Jakarta, S3 Student Education Management, State \\ University of Jakarta, Indonesia \\ ${ }^{1}$ Contibutor Email: isthifa@stkipgetsempena.ac.id
}

Received: March 28, 2017

Accepted: April 30, 2017

Published: May 27, 2017

Article Url: http://journal.scadindependent.org/index.php/jipeuradeun/article/view/133

\begin{abstract}
The purpose of this study is to determine the effectiveness of managerial skills of state elementary school principals in east Jakarta. The research involved 238 state elementary schools in east Jakarta and it had been selected from the target population of 588 state elementary school principals by using qualitative approach with path analysis methods. The research hypothesis testing showed that managerial knowledge had a positive direct effect on effective management. Therefore to improve the effectiveness of managerial skills of state elementary school principals in east Jakarta, thus management knowledge of education needed.
\end{abstract}

Keywords: Management Knowledge, Effective Managerial skills, Elementary School Principal 


\section{A. Introduction}

Indonesia is carrying out the construction in the situation of increasingly tight world competition. This development is the consequences of the industrialization and globalization. In order to deal with the development of the world that is increasingly advanced, especially information and communication technology required qualified human resources. This can be realized when supported by the education system. The education quality is one of the factors that determine and absolute in facing increasingly fierce competition.

The education meant is limited to formal educations which include primary education, secondary and high. There is a mutual relationship between the one of level with the level of education of the other. When the level of education is the basic quality, then it will give a positive contribution to the realization of secondary education and high quality anyway.

The strengthening of the ability of principal is expected to support the realization of the effective management of the school. To realize an effective school management takes a real effort of principal in communicating with the whole school community. Effective school management is expected to encourage a pattern of school life that is healthy so that it can improve knowledge management of principal in order to anticipate the changes that occur in the life of the community.

Angelo Kinicki (2011:345) said: "knowledge management is the development of tools, process, systems, structure and cultures explicitly to improve the creation, sharing and use of knowledge critical for decision making".

The implementation of managerial education that meets the principles of accountability seems to still have a long and winding road. Although the demands on education managerial accountable be expressed by many sides, not all education personnel greet it. It deals with the issue of the willingness, ability, perception and trust. Accountability of school will hopeful encourages school managerial effectiveness.

The school management is a part of the educational process that includes human resources, procedures, ideas, equipment and organizations to analyze issues concerning all aspects of the school program, including 
efforts to design, implement, evaluate, manage and solve the problems of education for the sake of continuous improvement. Through effective school management and is run by a principal who professional, competent, dedicated. Education process is expected to be qualified.

To realize the principal who has a national standard, one of the government's efforts is through the Principal Competency Test (UKKS) which started in March 2015. This competency test course to see the fact whether the principals. will meet national standards or not. Therefore, competency testing becomes very important, event the results need to be disseminated to the public to be taken into consideration when they choose a school for their children. Besides of that, the results of this competency test are also one form of transparency in education. Competency Test Results Principal (UKKS) in 2015 can be seen as follows:

\begin{tabular}{|l|l|l|l|l|}
\hline No & \multicolumn{1}{|c|}{ Criteria } & \multicolumn{1}{|c|}{ Score } & \multicolumn{1}{|c|}{$\begin{array}{c}\text { Range of } \\
\text { value }\end{array}$} & \multicolumn{1}{|c|}{ Total } \\
\hline 1 & Average & 50.58 & $>85$ & 0 \\
\hline 2 & Highest Value & 78.00 & $75-85$ & 6 \\
\hline 3 & Lowest Values & 12.00 & $65-74$ & 155 \\
\hline 4 & $\begin{array}{l}\text { Deviation } \\
\text { Standard }\end{array}$ & 9.90 & $50-64$ & 1.076 \\
\hline 5 & $\begin{array}{l}\text { Number } \\
\text { Participants }\end{array}$ & 2.238 .00 & $<50$ & 1.001 \\
\hline
\end{tabular}

With a minimum standard set of graduation 70 of the scale of 0 100, the results can be said that UKKS is not encouraging. This is reasonable because only $161(7: 19 \%)$ of the 2238 Elementary School Principals who passed, while 2,077 (92,81\%) Elementary School Principals still need further development. The average yield UKKS Elementary School in Jakarta in 2015 obtained a score of 50.58, still well defined minimum standard graduation 70 on a scale of $0-100$. This shows that there are problems with the managerial principal.

To realize managerial effectiveness is not easy, because it is influenced by various factors. Chukwuemeka said that the factors are identified that may affect managerial effectiveness is the experience, education and training, personal characteristics, development of managerial skills and ages. Thus, the main factors 
that influence the effectiveness of managerial experience of self is the principal itself, education and professional training, personal characteristics, the development of knowledge and management skills as well as age.

\section{B. Method}

This study use quantitative method, survey method and path analysis technique. The population of this study is all principals of Elementary School in East Jakarta. The sample of this study is partially of population. The sampling technique is done simple randomly. Target population affordable, the principals of Elementary School in East Jakarta amounted to 588. Counting the number of samples using the following formula Slovin:

$$
\begin{gathered}
n=\frac{\frac{N}{N d^{2}+1}}{\left(588 \times 0,05^{2}\right)+1} \\
n=\frac{588}{(588 \times 0,025)+1} \\
n=\frac{588}{2.47} \\
n=238.056 \text { responden }
\end{gathered}
$$

(it will be 238 principals)

Then, the total sample is obtained 238 principals, whereas for the test instrument as much as 30 principals. Collecting data for this study use questionnaire-shaped instrument. The instruments are tested before used in this study. The testing instrument covers the validity and reliability test. From these test results is obtained valid and invalid instruments. Invalid instrument discarded. Questionnaires were distributed to respondents to obtain the data about the overall variables studied.

\section{Research Finding}

\section{Managerial Effectiveness}

Effective word come from English language that is effective meaning is successfully or something done. In relation with the management, known as 
managerial effectiveness. According to Samuel C. Certo and S. Trevis Certo (2014:36) said: "managerial effectiveness is defined as the management's uses of organizational resources and the meetings of the organizational goals". Managerial effectiveness is defined as management's efforts to empower the organization's resources and achievement of organizational goals. Thus, there are two indicators of managerial effectiveness, namely the empowerment of organizational resources and the achievement of organizational goals.

In terms of being a manager, there are many different attribute that will lead to the success of the organization, as well as himself. Thus, one of the main attribute that will contribute to the effectiveness of managerial leadership. Leadership is the ability of someone to influence, motivate and enable others to contribute to effectiveness and achievement organizational of goals. John R. Schemerhon (2013:16) said "effective manager successfully help companies achieve both high performance and satisfaction in their work". Effective managers successfully helped more.

Achieve both high performance and satisfaction in the work. Furthermore Chuck Williams (2011:8) said "Also the manager must strive for effectiveness, which is accomplishing tasks that help fulfill organizational objectives such as customer service and satisfaction". Managers also must strive for effectiveness, completing tasks that help meet organizational objectives such as customer service and satisfaction.

\section{Knowledge Management}

Knowledge is a part of the truth that is believes to be using a variety of terms. Any matters relating to knowledge are matters concerning faith and truth. Knowledge is essentially the information or intimation known or recognized by someone. It is built on the experience of one's own self. Armstrong (2006: 175) states "knowledge is multifaceted and complex, being situated and abstract, implicit and explicit, distributed and individual, physical and mental, developing and static, verbal and encoded". Knowledge is something that face multiple and complex, both real and abstract, implicit and explicit, distributed and individuals, physical and mental, develops and static, verbal and encoded. 
Further confirmed by Ivancevich, Konopaske and Matteson (2008:245) "knowledge is defined as a conclusion or derived from analysis of data and information. Data are facts, statistics, and specifics. Information is the context in which the data are placed". Knowledge is defined as a conclusion or analysis derived from data and information. Data are facts, statistics, and specifics. Information is the context in which data is placed. Thus, knowledge can be obtained by observation and the observation made empirically and rationally.

Based on what has been disclosed above, the definition of knowledge management is about understanding someone specific data and information on the management of the organization needed to support the execution of the work. With indicators: definition of management, the nature and scope of management, management level and skill management.

\section{Influence of Knowledge Management and Managerial Effectiveness}

Knowledge management is a knowledge management effectively implemented in practice includes knowledge about the underlying science managerial effectiveness. More emphasis on managerial effectiveness in terms of understanding the process that the managerial activities of organizational resources in ways that right in order to achieve objectives. It is necessary that adequate management knowledge of managers. Management knowledge gained from learning about management. According to Pal (2010:1) "the objective of this lesson (management) are: to enable to define management; to describe the nature and scope of management; to know the difference between management and administration; to understand various levels of management; and to describe the various skills that are necessary for successful managers".

The above opinion is supported by the results of research conducted by Yang (2010:83-90) 'knowledge sharing would Facilitate the transformation on the individual collective knowledge without the existence of orphaned knowledge and knowledge depreciation. Furthermore, this would result in the advancement of learning and organizational effectiveness". Knowledge management owned a headmaster showed the specific understanding of the information and facts about the management of school organization needed to support the execution of the work, which appears in: understanding of planning, 
organizing, directing, and controlling the school community. Therefore, to realize the necessary managerial effectiveness of knowledge management.

Based on that, one may suspect there is a positive influence between knowledge management and managerial effectiveness.

\section{Discussion}

1. Managerial Effectiveness

From the data obtained in the field are then processed statistically to the distribution list of frequencies, the amount of class is calculated according to Sturges, obtained nine classes with a maximum score of 137 and a minimum score of 102 , so that the range of a score of 35 . The results of the calculation of the data obtained an average 119,21, normative 6,15 deviation, variance of 37.7953 , amounting to 119.0 median, and mode of 118 . The grouping data can be seen in the frequency distribution table as follows:

Table 2: Frequency Distribution Score of Managerial Effectiveness

\begin{tabular}{|c|c|c|c|c|c|c|}
\hline \multirow{2}{*}{ No } & \multirow{2}{*}{$\begin{array}{c}\text { Interval } \\
\text { Class }\end{array}$} & \multicolumn{2}{|c|}{ Limitation } & \multicolumn{3}{c|}{ Frequency } \\
\cline { 3 - 7 } & $\mathbf{U p}$ & Low & Absolute & Relative & Komulative \\
\hline 1 & $102-105$ & 101,5 & 105,5 & 4 & $1,68 \%$ & $1,68 \%$ \\
\hline 2 & $106-109$ & 105,5 & 109,5 & 14 & $5,88 \%$ & $7,56 \%$ \\
\hline 3 & $110-113$ & 109,5 & 113,5 & 21 & $8,82 \%$ & $16,39 \%$ \\
\hline 4 & $114-117$ & 113,5 & 117,5 & 51 & $21,43 \%$ & $37,82 \%$ \\
\hline 5 & $118-121$ & 117,5 & 121,5 & 56 & $23,53 \%$ & $61,34 \%$ \\
\hline 6 & $122-125$ & 121,5 & 125,5 & 52 & $21,85 \%$ & $83,19 \%$ \\
\hline 7 & $126-129$ & 125,5 & 129,5 & 34 & $14,29 \%$ & $97,48 \%$ \\
\hline 8 & $130-133$ & 129,5 & 133,5 & 5 & $2,10 \%$ & $99,58 \%$ \\
\hline 9 & $134-137$ & 133,5 & 137,5 & 1 & $0,42 \%$ & $100 \%$ \\
\hline
\end{tabular}

Based on the above table, the next will be created histogram. There are two axes are required in making histogram, they are vertical axis as absolute frequency axis, and the horizontal axis writing class boundaries interval that is from 101.5 to 137.5 . These prices derived by subtracting the number of data is the smallest 0.5 and adding 0.5 each class limit ceiling. Histogram graph of the distribution of the managerial effectiveness data as shown in the following figure: 
Picture 1: Histogram Data of Managerial Effectiveness

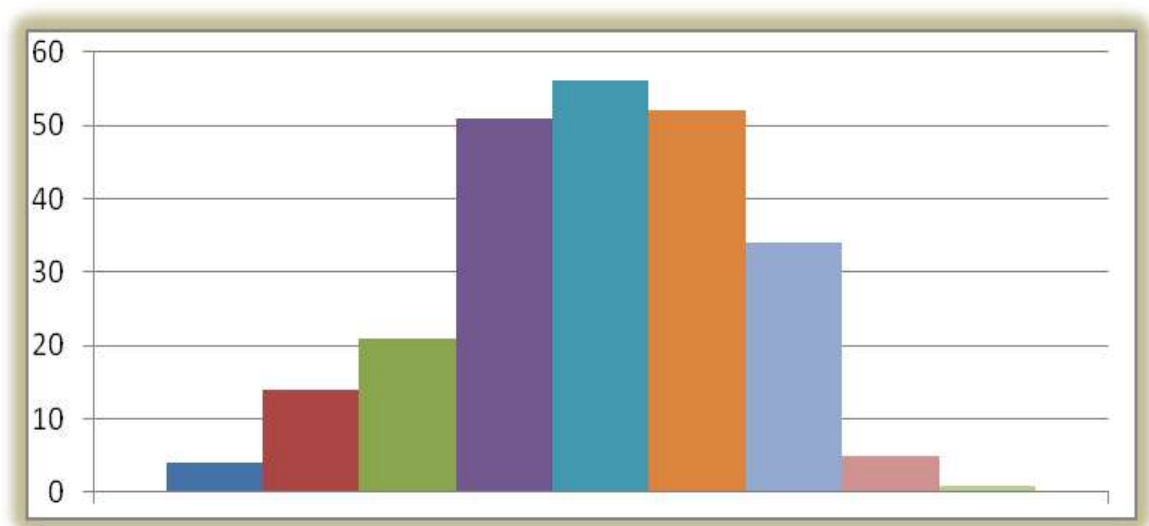

2. Knowledge Management

The data of knowledge management has a theoretical range of scores from 0 to 25 , and empirical score range between 8 to 25 . The results of the calculation of the data obtained an average of 19.38, standard deviation of 3.88 , the variance of 15.0985 , the median of 19,5 and 19 . The mode of grouping data can be seen in table frequency as follows:

Table 2: Frequency Distribution Score of Managerial Effectiveness

\begin{tabular}{|c|c|c|c|c|c|c|}
\hline \multirow{2}{*}{ No } & Interval & \multicolumn{2}{|c|}{ Limitation } & \multicolumn{3}{|c|}{ Frequency } \\
\cline { 3 - 7 } & Class & Up & Low & Absolute & Relative & Komulative \\
\hline 1 & $102-105$ & 101,5 & 105,5 & 4 & $1,68 \%$ & $1,68 \%$ \\
\hline 2 & $106-109$ & 105,5 & 109,5 & 14 & $5,88 \%$ & $7,56 \%$ \\
\hline 3 & $110-113$ & 109,5 & 113,5 & 21 & $8,82 \%$ & $16,39 \%$ \\
\hline 4 & $114-117$ & 113,5 & 117,5 & 51 & $21,43 \%$ & $37,82 \%$ \\
\hline 5 & $118-121$ & 117,5 & 121,5 & 56 & $23,53 \%$ & $61,34 \%$ \\
\hline 6 & $122-125$ & 121,5 & 125,5 & 52 & $21,85 \%$ & $83,19 \%$ \\
\hline 7 & $126-129$ & 125,5 & 129,5 & 34 & $14,29 \%$ & $97,48 \%$ \\
\hline 8 & $130-133$ & 129,5 & 133,5 & 5 & $2,10 \%$ & $99,58 \%$ \\
\hline 9 & $134-137$ & 133,5 & 137,5 & 1 & $0,42 \%$ & $100 \%$ \\
\hline
\end{tabular}

Based on the above table, the next will be created histogram. There are axes are required in the manufacture of the histogram vertical axis as absolute frequency axis, and the horizontal axis as the axis of the score of 
knowledge management. Histogram graph of the data distribution knowledge management such as shown in the following pictures:

Picture 1: Histogram Data of Managerial Effectiveness

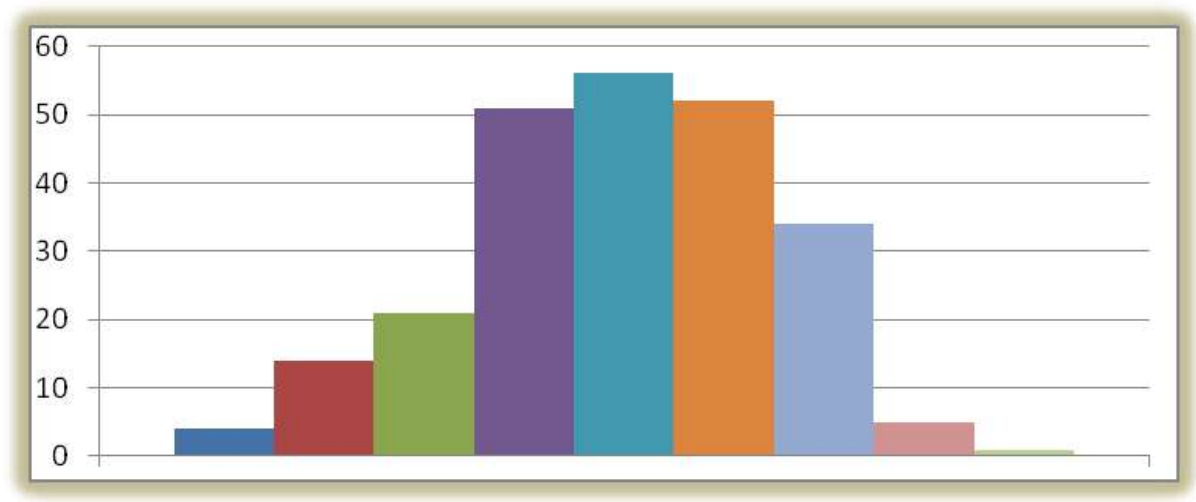

3. Direct Positive Impact on Managerial Effectiveness against Knowledge Management

The results of hypothesis produced finding that knowledge management was a direct positive influence on managerial effectiveness. Based on these findings, we can conclude that managerial effectiveness is directly affected positively by knowledge management. Increased knowledge of management will lead to increased managerial effectiveness.

Knowledge management is a knowledge management effectively implemented in practice includes knowledge about the underlying science managerial effectiveness. Managerial effectiveness is more emphasis on understanding the process of the managerial organizational resources activities with the right ways to achieve the goals.

It is necessary, the adequate of knowledge management of principal. Knowledge management is gained from learning about management. According to Pal purpose of studying management are as follows: "The objectives of this lesson (management) are: to enable to define management; to describe the nature and the scope of management; to know the difference between management and administration; to understand various level of management; and to describe the various skills that are necessary for successful managers. 
The above opinion is supported by the results of this study conducted by Yang as follows: "knowledge would sharing facilitate the transformation of the collective individual knowledge to organizational knowledge without the existence of orphaned knowledge and knowledge depreciation. Furthermore, this would result in the advancement of learning and organization. Eventually, the enrichment of organization effectiveness".

From here, we can see that the knowledge management directly influences on the managerial effectiveness. It means knowledge management of principal which can increase managerial effectiveness in public primary school in East Jakarta.

\section{E. Conclusion}

Knowledge management is a positive influence directly on managerial effectiveness. It means the knowledge management of principals which can increase managerial effectiveness on primary school, Administration city in East Jakarta.

Knowledge management can increase managerial effectiveness. If the principals have high management knowledge will enhance the managerial effectiveness. It can be done by performing learning relating to knowledge management. Principals who have difficulty in the mastery of knowledge management should be willing to constantly change and forward thinking. Orientation expected is the sensitivity of the principal starting from him self.

Principals need to do the following: (1) understand their duties and obligations, (2) understand the organization's need as, (3) organizational climate school, (4) understand the organization's problem, (5) capable of mapping the priority development of the organization, (7) be an example as well as the other aspects crucial for the organization.

The principal in developing mastery of knowledge management can start from himself. He must be willing to constantly evolve to keep abreast of regulations, policies, and other conditions that come from internal and external to the organization. Principals who are not sensitive to developments will have difficulty because of the policies that are 
managerial currently developing very rapidly as the development of information and communication systems.

Ideally, a principal must know and understand before his men so that can pursue his men, especially teachers.

\section{Bibliography}

Amstrong, Michael. (2006). A Handbook of Human Resources Management Practice. Philadelphia: Kogan Page Limited.

Bateman, Thomas S. Scoot A. Snell. (2015). Management Leading \& Collaborating in a Competitive World 11 edition. New York: MoGraw-Hill.

Campling, John, et.al. (2006). Management. Sydney: John Wiley \& Sons Australia, Ltd.

Certo, Samuel C. \& S. Trevis Certo. (2014). Modern Management: Concepts and Skill. 13th ed. England: Pearson.

Colquitt, Jason A, Jeffrey A. Le Pine and Michael J. Wesson. (2009). Organizational Behavior: Improving.

Daft, Richard L. (2014). New Era of Management. 11 Edition. Canada: SouthWestern Cengange Learning.

Griffin, Ricky W. (2013). Management Principles and Practices. 11 edition. Canada: Sout-Western Cengange Learning.

Ivancevich, John M. (2010). Human Resources Management. New York: McGraw-Hill Irwin.

Ivancevich, John M. Robert Konopaske \& Michael T Matteson. (2014). Organizational Behavior and Management. 10 edition. New York: McGraw-Hill Irwin.

Jones, Gareth R, Jennifer M. George. (2014).Contemporary Management. 8 edition. Singapore: McGraw-Hill.

Kemal, Isthifa. (2016). Manajemen Kewirausahaan Melalui Strategi Berbasis Sekolah di Islamic Solidarity School. Jurnal Of Management In Education (online). ISSN 2541-2140.

Kinicki, Anggelo, Brian K. Williams. (2013). Management a Practical Introduction. 6 edition. New York: McGraw-Hill. 
Kreitner, Robert Angelo Kinicki. (2011). Organizational Behavior. 9 edition. New York: McGraw-Hill.

Mathis Robert L. John H. Jackson. (2011). Human Resources Management. Mason, USA: Sout-Western Cangange Learning.

Mullins, Laurie J. (2005). Management and Organizational Behavior. Essex, England: Pearson Education Limited.

Robbins, Stephen P. \& Timothy A. Judge. (2013). Organizational Behavior. New Jersey: Pearson Education Inc.

Schemerhorn, Jr. John R.(2013). Introduction to Management. Lowa, John Wiley.

Schermerhorn Jr, John R, Paul Davidson, Peter Woods, Alan Simon \& Ellen McBarron. (2014). Management. 5 edition. Asia: Wiley.

Schermerhorn, John R. Jr et al. (2012). Organizational Behavior: Experience, Grow, Contributed. New Jersey: John Willey \& Sons, Inc.

Steinbach, M., \& Afroozeh, S. (2016). Comparative Education in The Educational Systems and Problems in Likenesses and Differences Between Regions of The World. Jurnal Ilmiah Peuradeun, 4(3), 333-346.

Sulaiman, S. (2015). Classroom Management and the Implications to Quality of Learning. Jurnal Ilmiah Peuradeun, 3(3), 431-440.

Walidin, W. (2016). Informal Education as A Projected Improvement of The Professional Skills of Employees of Organizations. Jurnal Ilmiah Peuradeun, 4(3), 281-294.

Williams, Chuck. (2008). Effective Management. Ohio, USA: Thomson Higher Education.

Williams, Chuck. (2011). Management. 6 edition. USA: South-Western Cengange Learning.

Yukl, Gary. (2006). Leadership in Organization. New Jersey: Peardon Prentice Hall, Inc. 